\title{
The Complexity of Evil: a Multi-Faceted Approach to Genocide Perpetration
}

Die Mikro-Dynamiken, wer sich warum an einem Genozid beteiligt, sind in der Friedens- und Konfliktforschung bislang wenig erforscht. Entsprechend existiert keine erkennbare, umfassende Theorie zu dieser Thematik. Ziel dieses Beitrags ist, die psychologische, politikwissenschaftliche und soziologische Literatur sowie journalistische Untersuchungen zu Fällen wie dem Holocaust, dem armenischen Genozid und dem Hutu-Genozid an den Tutsis in Ruanda zu beleuchten. Aus dieser Fülle an empirischen und theoretischen Ergebnissen werden generelle Einsichten über die Mikro-Dynamiken von Genozid herausgearbeitet und zu einer übergreifenden Theorie der (Nicht-)Beteiligung von TäterInnen an Genoziden zusammengeführt. In einem ersten Modell werden einige hinreichende, aber nicht individuell notwendige Bedingungen für eine Beteiligung identifiziert. Ein zweites Modell zeigt unterschiedliche Pfade zur freiwilligen, unfreiwilligen, aber überzeugten und gezwungenen Beteiligung auf und differenziert diese von der Nicht-Beteiligung. ${ }^{*}$

Schlagworte: Genozid, Täter, Motivationen, Pfad, Sozialpsychologie

\section{Prelude}

1942. The depths of occupied Poland. Simon and his 500 comrades gathered around Major Trapp who solemnly announced today's actions: rounding up and shooting the Jews of Jósefów. The men piled into trucks, and Simon felt queasy. But what could he do? An order is an order and he shot several people that day.

1994. Nyamata. Pancrace and a group of friends go out to the swamps around town in search of hiding Tutsis, as they have for the past few days. They find a Tutsi girl and Pancrace cuts her throat with a Machete, helping rid the community of a further »cockroach ${ }^{1}{ }^{1}$

* Ein englischsprachiges Abstract befindet sich am Ende des Heftes.

1 The stories are based on circumstances described in Browning ([1994] 2001) and Hatzfeld (2004). 
Hannah Arendt (1963) coined the much-quoted phrase »the banality of evil« when reporting on the court-case against Adolf Eichmann in Jerusalem. While the two cases above demonstrate how simple and banal motivations can be to participate in genocide, they also show how different they can be for participating in the same act. Contemporary, academic literature has focused on understanding the dynamics of individual cases and trying to comprehend psychologically how ordinary people could commit such heinous crimes. There have been a wide range of excellent studies on the role of Reserve Police Battalion 101 in Poland of 1942 (Browning [1994] 2001) or of local perpetrators in Rwanda's genocide of 1994 (Straus 2006; McDoom 2008). While these individual explanations are helpful, they are incredibly diverse and together they paint a very messy picture. It is important to take a step back and see the bigger pattern: what do these cases have in common? What can be generalised?

This paper tries to resolve these questions by synthesising the case study literature of political scientists, sociologists and historians with the insights of social psychologists into one general model of genocide perpetration, both demonstrating the complexity of these micro-level dynamics and overcoming the monocausal nature often implied in other studies as they focus on just one or very few factors. ${ }^{2}$ Most studies cited in this paper are on Rwanda and the Holocaust, though a few works on the Armenian genocide and the former Yugoslavia have also been reviewed. »Only by weaving ideas from many disciplines into a cohesive tapestry will we begin to understand extraordinary evil « (Waller 2002: 11), and this paper attempts to bring together the fruits of different disciplines. The general model developed in this paper is able to account for the breadth of different types of perpetrators across time and space that have been empirically described while also having enough depth to understand how and why each individual becomes involved. The research questions read:

\section{Why do people participate in genocide - what are their motivations? \\ 2. Why do some participate in genocide while others do not?}

2 While the work in this paper is not a formal model, the contribution consists of a systematic presentation of different factors which can cause participation in genocide. The model does not demonstrate strict sufficiency of causes, nor mathematical probabilities of participation, but it will provide a systematic and comprehensive overview of factors which are influential across multiple cultural settings and multiple individual contexts. I follow Evan S. Lieberman's use of the term model which »implies only a general theoretical argument that relates explanatory to outcome variables, and should not be taken to imply a ^formal model« (Lieberman 2005: 438). 
Finding answers to these questions on individual-level motivations is an important endeavour for furthering our knowledge on how genocides occur. While there may be an idea proposed or even a command issued by political leaders, genocide needs »foot-soldiers « to actually carry out the dirty work of killing the members of the victim group. The true horror of genocide is the fact that ordinary people become mass killers and without them the genocides would not unfold. What motivates these people is thus an important aspect of understanding the picture as a whole.

This paper will, after a brief definitorial excursion in section 2, present a model uniting the overwhelming wealth of ideas in the literature on what fundamental motivations can lead people to genocide participation, identifying obedience to authority, peer pressure, role expectations, coercion, opportunism, fear, threatened egotism, ideology and sadism as causes. To fully understand genocide participation, one must avoid sampling on the dependent variable »participation «; selection bias can only be prevented by analysing both perpetrators and non-perpetrators and identifying the differences between each. Section 4 thus differentiates between willing, persuaded and coerced participants, and non-perpetrators. This inductive process of creating a general model of genocide participation is complex and this paper's contribution is the attempt to develop a purely theoretic model, knitting together ideas from across social science. It will remain for future research to test it empirically. In section 5 a brief outlook will be presented on how such research could be structured and what challenges will have to be overcome, before concluding in section 6 .

\section{What is being studied?}

Much perpetrator research has been devoted to understanding Adolf Hitler, Pol Pot and other leaders whose brainchild genocides have been. Here, the focus will be not on these perpetrators in the highest echelons of power, but on the people on the street who participated, leaving their country ravished. While genocide is an inherently state-led phenomenon, due to its massive proportions it needs the participation of foot-soldiers at the local level, people who join the process, soldiers, paramilitaries and civilians - these are mostly ordinary people who live inconspicuously in their societies before and after their crimes, and it is the aim of this paper to explain why and how they climbed (or slid) into this abyss of human behaviour, and why others did not.

Genocide is defined here as »a form of one-sided mass killing in which a state or other authority intends to destroy a group, as that group and membership in it are defined by the perpetrator" (Chalk/Jonassohn 1990: 26). The advantages of this 
phrasing are the subjective definition of the victim, one-sidedness of violence, the stipulation of intentionality, and the state as an actor, most elements not found in their entirety in other definitions.

Perpetrators of genocide are seen as "any person who participated in an attack against a civilian in order to kill or inflict serious injury on that civilian. Perpetrators thus would be those who directly killed or assaulted civilians and those who participated in groups that killed or assaulted civilians « (Straus 2006: 102). This paper also includes those who participate through bureaucratic or logistical assistance, as their participation is pivotal to the success of genocide. These must be differentiated from bystanders who see the genocide happening, but do not participate nor hinder it.

\section{Why do people participate in genocide?}

This section presents a general model of why people participate in genocide. All humans are capable of evil and thus of genocide perpetration, yet there must be a motivation behind participation. This model will systemise the wealth of case studies and psychological analyses into a more coherent and simple form, visualising the results in figure 1. While most authors present their results as the determining factors of genocide participation, these variables may explain one case well but often fail in others. Here, these works will be brought together and one model which fits all developed. Nine independent variables determine the possibility of participation, while further facilitative factors can make participation easier to cope with. Moreover, the more independent variables and facilitative factors are present, the more likely participation is.

\subsection{Perpetrators as ordinary people}

A consensus in the interdisciplinary literature has emerged that participants in genocide are neither demographically nor psychologically aberrant, they are ordinary men (Browning [1994] 2001). Both statistical and qualitative comparisons of perpetrators and non-perpetrators have predominantly found few or no differences between the two groups (Browder 2003) and perpetrators have variously been described as "extraordinary only by what they did not by who they were« (Waller 2002: 8).

In Rwanda perpetrators do not deviate from the norm on anything but gender with most participants being male; they are comparable on marital status, fertility rates, occupation, social networks with Tutsi friends, neighbours, or relatives (Fujii 2009: 3), as well as education and religion (McDoom 2008: 245). In Germany, Christopher 
Browning describes the Reserve Police Battalion 101 as made up of »middle-aged family men of working- and lower-middle-class background from the city of Hamburg " (Browning [1994] 2001: 1). Situational influences generally have been accepted as significantly more explanatory than individuals' personalities or socioeconomic characteristics - metaphorically, perpetrators are not bad apples, but in a bad barrel (Zimbardo 2008: 197).

\subsection{Factors making participation possible}

This section introduces the crux of motivations for genocide perpetration; the nine variables determine the possibility of participation: in order to become a perpetrator, one of these factors must be present, though it is any one of the nine which is necessary. They are, however, not sufficient conditions for participation as the presence of each individual factor does not necessitate participation, but makes it possible. For instance, being a sadist, one will have a motivation for participation. Being afraid, or having peer pressure exerted, one has a motivation. But in these cases while one has a motivation, it is not clear that this will cause participation in every case. This is obviously not a deterministic process, and even if one or two of the independent variables are present, someone may not necessarily become a perpetrator; it just means that one has a motivation to participate. This is a distinction not often made in the literature, but it must be emphasised here. Nevertheless, the more of these conditions that are fulfilled, I suggest, the more likely participation is. Whether someone then actually participates is described in the second model in section 4.

While the model sees all the variables as theoretically equal until empirical testing has been conducted, differentiating the factors into three sub-categories is helpful. This clustering into broader categories of factors which can motivate people to participate in genocide underlines that while many authors focus on singular aspects in their analyses, much of this empirical work can valuably be brought together. The first two factors, ideology and fear, relate to the individual's perception of an outgroup; the next three, obedience to authority, peer pressure, and coercion, are constituted on relationships with the in-group or persons within this group; finally, four factors will be presented which focus on the individuals themselves: role expectations, self-interest, threatened egotism and sadism. Role expectations, however, also have a strong aspect of in-group dynamics. 
Figure 1: Why do people participate in genocide? What are their motivations?

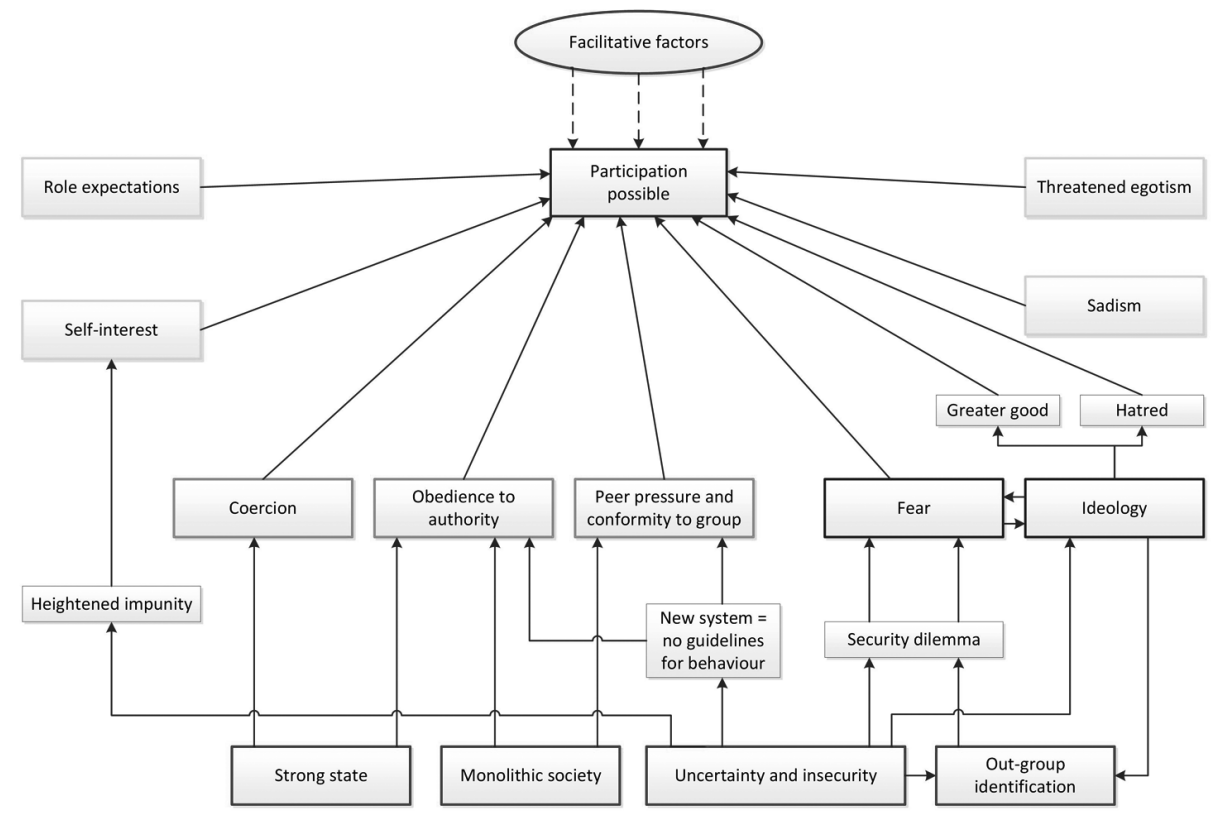

Source: Own diagramme

\subsubsection{Genocide motivations: individual's perception of an out-group}

\section{Ideology}

In popular understandings, this is probably the single most important factor for determining participation in genocide. However, many in academia find that $»$ deep hatreds or fervent ideological convictions are not necessary to explain the behaviour of most perpetrators « (Valentino 2004: 31; see also Mueller 2000: 50; Browning [1994] 2001: 73); while hatred and ideology are certainly two distinct concepts, they certainly interact and complement each other. While the concept of ancient hatreds as an explanation is widely rejected in academia, certain ideologies purported by genocidal elites, utilise a constructed notion of hatred towards the victim group as an ideological legitimation of the genocidal process, and in turn stoke fears about potential threats posed by this group. 
Many agree that anti-Semitism was widespread in the German population during the Holocaust, but while Daniel Goldhagen proposes that this was widely eliminationist (Goldhagen 1996), this is debatable as many may have been anti-Semitic but did not necessarily advocate the killing of all Jews (Haberer 2001: 398). Also in Rwanda, prejudices against Tutsis, or nationalist feelings were no more prevalent among people who participated than those who did not (McDoom 2008: 255). Nonetheless, some perpetrators are »true believers « and, thus, it becomes the first element of this model. They are convinced that the killing is »both necessary and just « for the greater good, or participate because they hate the victims, while even being revolted by the killing itself (Valentino 2004: 41). Further, ideology can facilitate killing as it can legitimise it and thus help conquer cognitive dissonance (see below), and also the ideological fervour of a few fanatics can normalise »criminal acts of killing as ordinary acts of duty« (Haberer 2001: 401).

\section{Fear (and other emotions)}

The second out-group oriented participation motivation is emotions. An emotion is »a mechanism that triggers action to satisfy a pressing concern « by raising the saliency of a certain desire over other competing desires; it can thus explain motivational shifts (Petersen 2002: 17-20). The emotion is triggered by structural change, and once generated creates feedback on beliefs and how new information is processed. A security situation, for instance, heightens the desire for safety, creating the emotion fear; this reinforces beliefs about the threatening group and frames new information in security terms (Petersen 2002: 22).

At the macro-level, most authors emphasise the importance of political upheaval, war or revolution in causing genocide(Melson 1992:21; Rummel 1994:22), emotions providing a micro-level mechanism of how this can motivate individuals to participate. Roger Petersen (2002: 19) focuses on three instrumental emotions, fear which arises from safety concerns, hatred from historical grievances, and resentment from self-esteem discrepancies, and on the non-instrumental emotion rage.

This section will focus on fear as it is prevalent in the literature, and many aspects of hatred and resentment are dealt with in the sections on ideology and self-interest (especially resentment of material wealth and revenge in the context of personal or political feuds), respectively. However, a significant minority of participants in Omar McDoom's (2008: 285; see also Straus 2006: 122) study reported that people killed out of anger for President Habyarimana's death, vengeance presenting a mixture of resentment, hatred and especially rage. 
McDoom (2012) sees emotions as especially important in determining support for violence, while material opportunities are most important for actual participation. This paper proposes that this process of out-group identification and its consequences for the in-group take place in a context of uncertainty and can be influenced strongly by the ideology prevalent in society. Further, McDoom (2012) develops a four-point model of mechanisms in reaction to a security threat: (1) As a threat grows, boundaries between groups become activated, and a conflict becomes seen, for instance, as ethnic, what James Waller (2002: 241) terms an »us-vs.them « mentality; (2) as the threat grows, the derogative references to the out-group increase, as they are framed against negative historical narratives and cultural beliefs. Waller (2002: 155) calls this xenophobia which goes hand-in-hand with a desire for social dominance over the other group (see also Gourevitch 1998: 128-129); (3) also, out-group members become perceived as ever more homogenous and deindividuated, thus perceiving even unarmed members of the group as a threat; (4) finally, the demand for in-group loyalty rises. This process of out-group devaluation and identification with the in-group differentiates strongly between the groups and is a precondition for several of the factors described in section 3.3, such as dehumanisation of the victims. Also it is necessary to identify »the enemy« in order for the emotion fear to be produced.

Furthermore, this out-group identification can be influenced by ideology, constituting the groups themselves, as well as assigning negative connotations to this outgroup; such is the concept of »negative racial stereotyping « prevalent in most genocides (Browning [1994] 2001: 162). Racial stereotyping and deindividuating the enemy to one homogenous mass allow civilians, in war, to be seen as the enemy and calls for their killing to resonate (Browning [1994] 2001: 162; Straus 2006: 226). Also, through the act of genocide itself, it is possible to further reinforce the identification with the in-group, as demonstrated by Ann Lee Fujii $(2009: 147,155)$ with intense group ties between perpetrators in Rwanda being solidified during the acts of genocide themselves. Killing Tutsis »brought people together« (Gourevitch 1998: 96).

What both Petersen and McDoom have in common is that their models start with structural changes which elicit, for example, a threat. Identification with groups does not have to be seen as a cause of conflict but as emerging in the process of it out of fear itself (Mann 2005: 424). These thoughts are embedded in a context of security concerns, at its most extreme in the idea of a security dilemma. ${ }^{3}$ In this context, fear may cause identification with the in-group and be a precursor to violence; however,

3 For an excellent presentation of the security dilemma and ethnic conflict, see Posen (1993). 
in a spiral downwards, this violence reinforces the fear itself (Snyder/Jervis 1999). Neither, however, can account for differing reactions to fear within one community - why do some avoid participation despite their fear?

Fear seems to be especially pertinent in the context of Yugoslavia and Rwanda, with the identification of the out-group becoming ever more fixed during the conflict. In this context of uncertainty and fear caused by war, and the legitimisation this war gave to the killings, the emotional reaction of fear after a homogenisation of the out-group in Rwanda was to eliminate the local Tutsi civilians (Straus 2006: 226). While fear is cited as a reason for participation, McDoom does not find that perpetrators in Rwanda feel any more threatened, have more security fears or perceive greater ethnic distance than non-perpetrators (McDoom 2008: 261, 285). But while both may have been fearful, this fear could still be a perpetrator's motivation for participation; the fearful non-participant was just somebody who was not recruited (see model 2, presented in figure 2).

\subsubsection{Genocide motivations: relationships with the in-group or persons within this group}

\section{Obedience to authority}

Now to the dynamics of the in-group: Obedience to authority is the most cited factor in the academic literature on genocide participation and also the reason most perpetrators give: »I was just following orders «. These arguments are predicated on the 1960 s social-psychological experiments of Stanley Milgram (1963) in which participants were ordered by an experimenter in a white laboratory-coat to shock a confederate, someone who one assumes is also a volunteer but is actually part of the experiment set-up. $65 \%$ of participants shocked the other to the highest level possible despite pleas to stop and cries of anguish. The emphasis of obedience to authority lies not in the anticipation of coercion or social pressures, but on »seemingly voluntary entry into an authority system >perceived ‘ as legitimate creat[ing; author's note] a strong sense of obligation. Those within the hierarchy adopt the authority's perspective« (Browning [1994] 2001: 173) and act accordingly, following their superior's explicit or implicit orders. The authority of these superiors can be heightened in the context of a strong state which has already established channels of authority, thus possessing a high degree of credibility, which is important as $\gg$ a person must judge an order consistent with the role of the authority figure « (Kressel 2002: 157). Furthermore, in monolithic societies, societies with a $\gg$ small range of predominant values and/or limitations on the free flow of ideas « (Staub 2002: 16), this credibility is easier to convey as there are no dissenting opinions or competing 
logics. Further, situations of uncertainty and insecurity give rise to systems in which »people cannot call on previous guidelines for their new behavioural options « (Zimbardo 2008: 212) and thus many turn to authorities for guidance, and obedience to their commands will be higher (Staub 2002: 16).

In Rwanda, orders to kill Tutsis quickly »became a de facto basis for authority « and »killing became akin to policy « (Straus 2002: 66) - in short, it became »the law « (Straus 2002: 93; see also Gourevitch 1998: 123). Again, the strong state and previous traditions of community labour (Straus 2002: 82), with most actors seeing the state as the most influential actor in their lives (McDoom 2008: 265), gave credibility to the authorities and supported obedience.

Despite the strong impact Milgram's experiments had on scholarship about genocide participation, specifically on Holocaust perpetrators, there are a number of differences. (1) While Milgram's participants were assured that the other would not be harmed by the shocks, this cannot be claimed in the killing process of any genocide (Kressel 2002: 161; Waller 2002: 107). However, judging by the sweating, trembling, and stuttering exhibited by many participants in Milgram's experiments, it can be assumed that they too believed in the harmfulness of their deeds (Kressel 2002: 159). (2) »Milgram's subjects had little time to contemplate the implications of their behaviour « (Waller 2002: 108), whereas genocide perpetrators commit these acts repeatedly for months or years; however, the element of surprise and resulting compliance is mirrored in Browning's descriptions that, while only a few had let themselves be excused initially, »for many the reality of what they were about to do, [...] had probably not sunk in « (Browning [1994] 2001: 60). This served to overcome one's inhibitions and start off a process of moral disengagement and desensitisation that made future participation easier (see below). (3) The physical presence of the experimenter was pivotal to Milgram's experiments, as many participants repeatedly said they did not want to continue and were continually told they must. Empirically, however, perpetrators of genocide often commit their destruction even when not under the surveillance of authority (Kressel 2002: 161; Waller 2002: 107) - this gratuitous violence beyond the call of duty is best explained by the concept of »roles « described below, while obedience may be important in explaining initial participation.

Lastly, it is important to emphasise that merely following orders does not necessarily signal obedience to the authority issuing them (Kressel 2002: 149). A host of other motivations could be primary with the order just cloaking the participation in a mantle of legitimacy. Altogether, though, the evidence that authority is pivotal for some individuals' decision to participate merits its inclusion in the model. 


\section{Peer pressure and conformity to the group}

While Milgram's experiments have impressive results, obedience to authority varied between over $90 \%$ and under $10 \%$ depending on another factor: whether one was given confederates who were willing to perform the task or who refused to participate. These people acted as role models and facilitated the subject's obedience or disobedience (Zimbardo 2008: 272). Pressure can be applied both vertically, »exerted by those who are invested with authority « (Semelin 2005: 257), and horizontally, in the form of peer pressure, driving people to question their original inclinations towards disobedience or non-participation (Kressel 2002: 168). This is the fourth factor to be incorporated into the model. Non-participation can entail high costs: social stigma, pecuniary sanctions or physical harm (McDoom 2008: 237). Such social pressures, however, are subtle and indirect and people tend not to cite them as a motivation for participating as it does not appear to relieve one of responsibility for one's actions (Browning 2002: 174). Peer pressure can manifest itself in informational social influence, that is using peers as a source of information on how to make decisions in an uncertain situation, and normative social influence. This is »operative when we conform so that we will be liked and accepted by other people « - for instance, the reserve policemen perceived nonconformity as »refusing one's share of an unpleasant collective obligation « (Waller 2002: 218-219), and not wanting to leave »the dirty work « to their comrades (Browning [1994] 2001: 184). Not conforming could also be interpreted as a »moral reproach of one's comrades: the nonshooter was potentially indicating that he was >too good « to do such things « thus, most non-perpetrators framed themselves not as »too good « but »too weak «, not challenging but legitimising their comrades' »toughness «. $80-90 \%$ of the men »proceeded to kill, though almost all of them - at least initially - were horrified and disgusted by what they were doing " (Browning [1994] 2001: 184-185). It was harder to go against the group than to shoot.

Daniel Goldhagen tries undermining this logic of mass participation. Peer pressure cannot work on more than a few group members, especially over long time spans: »If a large segment of a group [opposes; author's note] an act, then the social psychological pressure would work to prevent, not to encourage, individuals to undertake the act «(Goldhagen 1996: 383-384; italics in original). This, however, neglects the informational problems of the people themselves. Because participants cannot always know what others think, they may conform to norms that are not actually the others' beliefs - they may all participate and feel they are conforming even if the majority deems the action wrong (Newman 2002: 60). 
One must distinguish further between two types of peer pressure, one extrinsic in which other group members pressure a person actively, another intrinsic in which an individual feels the need to act in conformity to other group members (Baumeister/Campbell 1999). This latter pressure was demonstrated by social-psychologist Solomon Asch (1963): 70\% of subjects concurred with obviously wrong answers if all confederates unanimously answered wrongly. Support by just one confederate, lowered knowingly wrong answers to under $25 \%$. Peers' actions have a significant impact on individuals' action, increasingly so in social situations which are new to the individual, in a context of uncertainty. Also, the homogenous culture of monolithic societies increases the effect of peer pressure as it minimises the feasibility of formulating alternatives.

\section{Coercion}

In contrast to obedience and peer pressure, where authority or peers are followed voluntarily, coercion entails the fear of repercussions for non-participation through either leaders or peers. This factor is commonly cited by perpetrators framing their participation as a decision made without a choice, e.g. Holocaust perpetrators seeing the alternatives to non-perpetration only as immediate execution or incarceration in a concentration camp. This rationalisation is empirically shaky in Germany as none »of the hundreds of postwar trials has been able to document a single case in which refusal to obey an order to kill unarmed civilians resulted in the allegedly inevitable dire punishment « (Browning [1994] 2001: 170). However, it is highly plausible that, at the time, they did not know of this lack of consequences and thus acted under false, yet credible pretences, thinking that evasion of punishment was only possible through participation. While Major Trapp - in Browning's analysis made it explicitly clear that no-one needs to participate if they do not want to, and thus, this factor is not at work there, this choice was not available elsewhere. In the Armenian genocide, Turkish soldiers who disobeyed deportation orders were shot (Mann 2005: 164, 168).

In Rwanda, intra-Hutu coercion is an important explanation given for participation in the genocide with coercive measures such as monetary sanctions and physical attacks, even as far as killing, levied against non-participants (McDoom 2008: 265; Straus 2006: 96, 136). Further, a strong state, high population density and increased visibility due to the topography of the country increased capacity for surveillance and reduced options for exit and escape, creating an environment in which coercion could credibly be enforced (Straus 2006: 214-215). Thus, perpetrators often portray their decision as a choice between participation and strict punishment, sometimes 
even death. However, while exit options may have been limited, they did exist (especially due to changing threats of coercion), and if coercion really was the primary reason for participation, it is surprising that there is »not more evidence of people hiding, shirking, or finding ways out of participating when they could« (Fujii 2009: 166).

\subsubsection{Genocide motivations: the individual himself}

\section{Role expectations}

Social situations can change people so much that they act in ways not predictable from their dispositions. Especially when people take on roles, or better said, when they internalise the values and beliefs of a role. The role then

»shuts off the traditional morality and values that govern their lives when they are in snormal moder. The ego-defence mechanism of compartmentalisation allows us to mentally bind conflicting aspects of our beliefs and experiences into separate chambers « (Zimbardo 2008: 214; italics in original).

Thus, a person can start committing actions that would normally be unthinkable. The power of roles was most evocatively shown in Philip Zimbardo's Stanford Prison Experiment in which some of the randomly assigned »guards soon came to abuse their newfound power by behaving sadistically« (Zimbardo 2008: 297). It became evident that when one performs the behaviours appropriate for a given role, there is a merger of role and person in which one often acquires the attitudes, beliefs, values, and morals consonant with that role and its behaviours « (Waller 2002: 221). This factor is especially useful in explaining the »smile problem«: gratuitous violence which goes beyond the call of duty. The perpetrator is no longer an individual forced to participate, but someone in a role, conscientiously playing out their part (Roth 2004: 214; Zimbardo 2008: 216). Also, the tendency to accept a role is stronger when peer pressure to this end is exerted and participation may also be contingent on societal parameters exerting pressure to take on a role, such as a strong state or a monolithic society.

Waller posits that if the values of the role conflict with those of the person, over time there is a "psychological tendency to adjust their underlying beliefs and values to what is consistent with their roles «, thus actually re-shaping the person itself into a more violent, aggressive person capable of continually committing acts of genocide (Waller 2002: 224). On the other hand, George Browder argues that a role need not be internalised fully, but can be »worn «, that is temporarily identified with (Browder 2003: 494). This can better explain how people are »normal« before they 
participate in genocide and afterwards, as they need only slip into their genocidal role and can afterwards continue their lives unabated; this is akin to John Steiner's concept of sleepers lying »dormant until circumstances or specific events will activate him or her and produce behavioural traits not apparent before« (Steiner 1980: 431).

Empirically, this is also helpful in explaining the participation of bureaucrats in the administration of genocide, or of professionals, e.g. doctors, in practices opposed to their normal profession such as torturous medical experiments. By taking on a separate role, they are able to perform the tasks required while alleviating psychological stress.

\section{Self-interest and opportunism}

As rational actors, humans seek to pursue a course of action which will produce the subjectively most optimum outcome. While ideology, safety, etc. all play a part in this, the model must also be able to and can account for a type of perpetrator who participates in order to forward his own private self-interest. This section identifies five different rational motivations for genocide participation. In the context of uncertainty typical of most genocides, a heightened sense of impunity can emerge, which facilitates individuals following their opportunistic preferences.

Material enrichment is the most prevalent and evident of the opportunist factors (Fein 1990; Kuper 1981: 87; Semelin 2005: 242; Valentino 2004): people are encouraged to participate with $\gg$ the opportunity to strip victims of their wealth and property - either by looting it outright, or by purchasing it at desperation prices and to occupy their forcibly vacated dwellings « (Jones 2006: 264). While Roy Baumeister (2002: 253-254) sees material gain as a secondary cause of participation during the Holocaust, other cases do show more evidence for its primacy. In the Armenian genocide, Michael Mann (2005: 167) describes looting as the primary motivation of most paramilitaries for participating in the killings, while similarly in Yugoslavia bands of thugs would commit killings in order to seize plunder (Mueller 2000; Kressel 2002: 31). Finally, in Rwanda material gain figures prominently in the eyes of perpetrators about why others participated (McDoom 2008: 285), and Luke Fletcher (2007: 33) describes quite graphically to which excesses people participated in order to enrich themselves.

Local power struggles: This factor has been described richly for Rwanda: in the uncertainty after President Habyarimana's assassination and the beginning of violence traditional power relationships were upended and a space of opportunity emerged, in which authority was up for grabs (Straus 2006: 65, 76, 96). By becoming 
radicalised, calling for Tutsi elimination and leading killings, local elites were able to remain in or attain power (Fujii 2009: 129; Semelin 2005: 207).

Personal feuds: Furthermore, personal scores between neighbours could be settled, with an individual's hostility toward Tutsi neighbours normally pre-dating the genocide itself and being personal, rather than ethnic. There is also evidence of Hutu sons denouncing their fathers as traitors so as to inherit land (Fujii 2009: 136).

Career interests: In Browning's (2001: 75) study, interestingly, no-one mentioned that they participated to further their careers; however, several people stated that they had not participated because they did not want to seek careers in the police force back in Germany. From these narratives, it appears at least plausible that careerism can motivate participation. Also, while soldiers who disobeyed orders to deport Armenians were shot, the same was not true for their officers; however, it would have had a very detrimental effect on their careers, thus motivating many to participate despite their inhibitions (Mann 2005: 164).

Freedom from prison: In the Armenian genocide (Mann 2005: 167), Rwanda and Yugoslavia (Mueller 2000: 49, 61), criminals were let out of prison early if they agreed to participate in the killings. They were promised loot in return, but even the prospect of freedom must have been a strong incentive for their participation.

\section{Threatened egotism}

The penultimate variable presented for this model of genocidal motivations is threatened egotism. People who have $»$ favourable views of self that have been disputed or impugned by others" (Baumeister 2002: 248) or »felt these views were being questioned, undermined, or attacked « have a tendency to react with aggressive behaviour (Baumeister/Campbell 1999: 218). This goes against theories that low self-esteem in general leads to aggression. Roy Baumeister (2002: 248) identifies those with high self-esteem but threatened as most hostile and aggressive, and those with high, unthreatened self-esteem least. The self-esteem itself can derive from personal factors but also from group traits which are lauded in a prescribed ideology. Thus far no empirical studies have looked into the role of threatened egotism in comparison to other factors in motivating genocide perpetrators, thus not yet allowing empirical substantiation for Baumeister's assertions.

\section{Sadism}

Sadism is »the derivation of pleasure from inflicting harm « (Baumeister 2002: 254). Opponent theory suggests that after the aversion of committing dreadful acts comes a pleasurable feeling of being restored to one's normal self. One can become 
addicted to this pleasurable feeling, thus, continually wanting to inflict harm in order to then enjoy the restorative reaction (Baumeister/Campbell 1999: 213-214).

Most agree the percentage of perpetrators who are sadists is tiny (Baumeister/ Campbell 1999: 254; Mueller 2000: 55), though Benjamin Valentino (2004: 40) suggests that while they may only be a fraction of the population, they can be a majority of the actual killers as not all people in society need to participate. Others maintain that sadists will be selected out of such proceedings because they are hard to control, as they enjoy the pain and killing itself, irrespective of the victim (Zimbardo 2008: 290) - thus, there is a disconnect between out-group identification and sadism. Empirically, selecting out is more likely, with Browning finding only one of the 500 soldiers of the Reserve Police Battalion 101 to be sadistic. A discrepancy could come because it is normally evaluated from the perspective of the victim who may misinterpret gestures as sadistic (Baumeister/Campbell 1999: 212). Nonetheless, it is sufficient motivation to merit inclusion in this model and many empirical descriptions of genocidal processes include reference to one or more perpetrators with sadistic impulses (among others Browning [1994] 2001; Mueller 2000; Straus 2006).

\subsection{Facilitative conditions making participation easier}

While the previous section focused on conditions which individually make participation possible, with it being necessary for one of the factors to be present for genocide to occur, this section identifies factors which are psychologically alleviating and thus make participation easier for the individual. While in the literature these variables are often implicitly portrayed as necessary or sufficient, they are not. Regarding sufficiency, for instance, dehumanising the victims makes it easier to kill them, but it does not give one a motivation to do so; as most people do not shoot all animals that they see, but would find it easier to shoot an animal rather than a human. Further, none of these factors are necessary, but when they are present, they make participation more likely. As the diagram of the model suggests, they impact the probability of participation directly and independently of the other variables, thus, augmenting the probability should one necessary variable be present. Dehumanisation, for instance, is facilitative, but not necessary, as the case of sadists demonstrate. In this section, the wealth of different ideas on facilitative conditions is subsumed under certain more general categories. 


\section{Gradual moral disengagement}

This is a gradual evolution described by Albert Bandura (1999: 203), also termed the continuum of destruction (Staub 1989), by which less harmful acts change an individual and make progressively more harmful acts possible. The perpetrator's self-concept changes gradually until truly harmful acts of genocide become psychologically possible. For instance, victims can be progressively more devalued in this process, while at the same time perpetrators get more and more used to committing violent acts (Staub 1989: 5, 17). This is also the process which serves as professional socialisation. In case moral scruples do re-emerge, $»$ the organizers of the genocide try to render the acts of mass murder as routine, making them as mechanical, repetitive, and programmed as possible« (Kressel 2002: 171). Browning (2001: 127) describes how horrified most were about the task they were to perform. They were being thrown in at the deep end without any time to gradually disengage. If they had first built up with less harmful acts, maybe they would not have been so revolted - much as they were not later.

\section{Bystander effects}

»The silence or inaction of others encourages perpetrators. Individuals feel emboldened by the mere presence of others, or else legitimized if others do not object « (McDoom 2008: 237). When others do not react to a situation and remain passive, this significantly undermines the probability of others responding to rescue, or perpetrators not participating (Staub 2002: 24). This is also a consequence of the social-psychology revealed in Asch's experiments presented in the section on peer pressure.

\section{Reduction of personal responsibility}

When people do not feel personally responsible for their actions, they are more likely to act against their moral standards as they do not feel that they need evaluate the actions as their own. When legal and moral responsibility is displaced to an authority, actions can be seen as direct orders and thus they need not feel personally responsible for the consequences. Thus, otherwise morally reprehensible actions become possible and as they do not feel to be »the actual agent of their actions, they are spared self-condemning reactions « (Bandura 1990: 196; Kressel 2002: 168). As already stated, genocidal acts nearly always happen in groups, and, in groups, individuals' sense of personal culpability is strongly diminished through diffusion, as »any harm done by a group can always be attributed largely to the behaviour of 
others « (Bandura 1999: 198). Further, through portioning the acts into small pieces, each seeming relatively inconspicuous, no-one feels that they are to blame for the genocidal outcome (Waller 2002: 212). Also, the more people are in a situation, the less likely someone is to intervene and stop the group from participating in genocide. Each of the observers assumes that the others could help and thus there is little pressure on him to be the one (Zimbardo 2008: 315). Wearing uniforms, costumes, or masks which disguise the identity of the participant can create an anonymity that reduces personal responsibility. This is especially the case if one would like to or is coerced to engage in practices that one might otherwise in a normal setting face social repercussions for, e.g. looting, raping, torturing etc. (Zimbardo 2008: 219). A culmination of the afore mentioned factors, leads to deindividuation-defined as a

"state of relative anonymity in which a person cannot be identified as a particular individual but only as a group member [with; author's note] decreased focus on personal identity, loss of contact with general social norms, and the submergence of the individual in situation-specific group norms « (Waller 2002: 216).

Aggressive behaviour becomes more likely as the deindividuated individual becomes disconnected from his personal standards and ceases to self-evaluate (Waller 2002: 216; Zimbardo 2008: 305).

\section{Resolution of cognitive dissonance}

Cognitive dissonance describes the »discrepancy between our behaviour and beliefs [...]. Dissonance is a state of tension that can powerfully motivate change either in one's public behaviour or in one's private views in efforts to reduce the dissonance « (Zimbardo 2008: 219); normally it is easier to adapt one's attitudes and beliefs, rather than change one's actions.

The first strategy for resolving cognitive dissonance is moral justification, a redefinition of the harmful behaviour as morally good and »serving socially worthy and moral purposes « (Bandura 1999: 194; see also Zimbardo 2008: 310). For instance, by portraying the killing as necessary for the security of the group or as selfdefence it can even become a moral imperative (Waller 2002: 186; Bandura 1999: 203). Also operative are exonerating comparisons: the utilitarian calculus of how much more harm is prevented than caused by committing the acts of genocide (Bandura 1999: 196). Further, individuals can rationalise that their non-participation will not change the victims' fate anyway. The fate of the Jews in the Holocaust 
and of the Tutsis in the Rwandan genocide was set - individuals maintained that non-participation would have been detrimental to themselves without serving to save the victims, and thus would have been pointless (Browning [1994] 2001: 72; Fujii 2009: 166). Also, euphemistic labelling, as the use of »sanitising « language to portray the terrible acts of genocide as positive or the agentless passive style attributing the acts more to general forces rather than individual actors, both making the acts more respectable and reducing moral repugnancy (Bandura 1999: 195).

The »tendency of people to believe that the world is just and that therefore people get what they deserve and deserve what they get «, is known as just-world-thinking. Victims are seen to »have earned their suffering by their actions or character« (Waller 2002: 250; see also Staub 2002: 22). Often this process can happen as a post hoc justification after aggression (Newman 2002: 54). This should be differentiated from ideological rationalisations that the victims deserve their punishment - the just-world-rationale is entirely inferred from believing in a just world in which people receive treatment due to them.

Through a division of labour, each individual can perform jobs that seem harmless enough in themselves. »After activities become routinized into detached subfunctions, people shift their attention from the morality of what they are doing to the operational details and efficiency of their specific job «, thus facilitating psychological alleviation (Newman 2002: 54; see also Waller 2002: 215; Browning [1994] 2001: 77). Bureaucrats organising logistics or soldiers rounding up and putting Jews on trains feel that they are not participating in the killing, although their participation is a necessary cog in the genocidal machine. The further the physical and bureaucratic distance from the killing, the easier participation becomes.

Humans find it difficult to mistreat other humans because of empathetic responsiveness learned during infant experiences (Bandura 1999: 200). However, most genocide scholars agree that if the victim group is removed from this »web of mutual obligations « and is dehumanised, then it is easier for the perpetrators to kill them as inter-human morality no longer has to apply to these creatures. ${ }^{4}$ Albert Bandura (1999: 200) showed this well in his famous experiment on dehumanisation: a group of students was to administer shocks to other groups of college students which were framed in dehumanised, neutral or humanised ways. The dehumanised situations led to significantly higher shocks than the neutral or humanised priming. It should be emphasised, however, that dehumanisation as a factor is not necessary, much less

4 Chalk/Jonassohn (1990: 29); see also Browning ([1994] 2001: 73); Fein (1990: 37); Kressel (2002: 172); Kuper (1981: 101); Rummel (1994: 22) and Zimbardo (2008: 223). 
sufficient given that most people do not have a history of brutality towards animals - dehumanisation makes it easier to be brutal, it is not the motivation for it.

\subsection{Redundant factors}

There are several factors mentioned in the literature which have not been found as empirically useful and which have consequently been excluded from the model. Due to the constraints of this article, a full treatment cannot be provided here. Difficult life conditions are hypothesised to create hardship and stress which then turn to violence (Staub 2002: 13), though this is disproved at least for the case of Rwanda (Straus 2006: 37). Similarly, there has been no empirical case made for environmental scarcity (André/Platteau 1998: 38; Fletcher 2007: 27) or deprivation (McDoom 2008: 251) directly impacting genocide participation, nor discriminating between perpetrator and non-perpetrator, respectively. Steven Baum (2008) posits that perpetrators are emotionally underdeveloped and, while this has not been empirically tested, it appears intrinsically interwoven with purely dispositional explanations which have been dealt with extensively and are mostly disproved (see above).

\section{Why do some participate in genocide while others do not?}

Now, a model in answer to the second research question will be sketched, thus attempting to systematically understand how, when and why ordinary civilian people come to participate in genocide. Model 1 (presented in figure 1) tried to show how it becomes possible for humans to kill other human beings and what their motivations could be in participating in genocide. This second model takes it a step further and presents the results in a tree diagram, depicted in figure 2, highlighting how highly dependent participation is on situational circumstances. Three types of perpetrator are identified: willing, unwilling but persuaded, and coerced participants.

Following from model 1, participation is possible if one of the necessary conditions is present and becomes more likely the more necessary and facilitative conditions are fulfilled. One can identify those who are willing and recruit themselves into participation; often the factors prevalent here are ideology, sadism, opportunity, fear and threatened egotism, though other factors can also be at work in addition to these. For those who are not willing volunteers, it becomes a logical necessity that they be recruited, that is coerced, persuaded or even just asked to join in. However, not all people are approached to participate in genocide. Who is approached in a recruitment attempt? 
Figure 2: How do people become participants or non-participants?

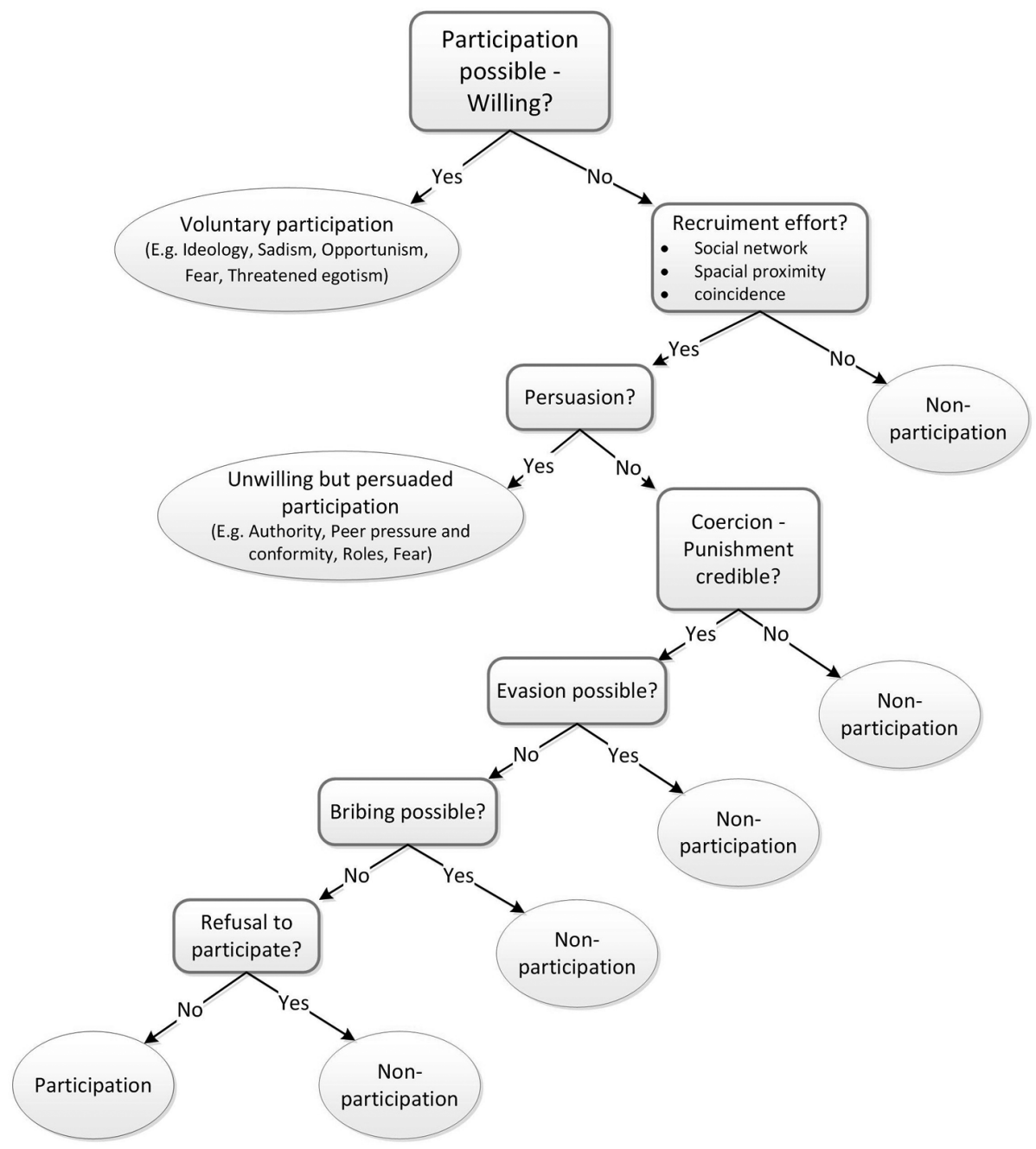

Source: Own diagramme 
McDoom's (2013) recent work using geo-spatial data on who participated in the Rwandan genocide finds evidence that perpetrators are more likely than non-perpetrators to live close to and in the same household as other perpetrators. This suggests the importance of social networks and spatial proximity: one is recruited by family members and close neighbours, providing evidence for the importance of social ties and situational peer pressure being exerted on some people and not on others (McDoom 2013: 3; Fujii 2009: 128). Further, social ties or household location proximate to leaders can account for differing patterns of selection into the violence (McDoom 2008: 235, 267), leaders recruiting the heads of ten nearby households, interestingly with households "generally represented by no more than one male member, such as the father or a son, as if the genocide was like umuganda [communal labour; author's note] «(Fujii 2009: 138; italics in original).

Further, coincidence or luck seemed to play a part as some people were $»$ in the wrong place at the wrong time« and were recruited walking along the road or in similar situations (Straus 2006: 139; Gourevitch 1998: 22). Those who were less fortuitous were approached for recruitment, others were luckier and became nonperpetrators. Finally, time also played a part as at some point genocide finishes and recruitment no longer happens.

If one was approached for recruitment, some were then persuaded by situational pressures or other factors, e.g. authority, peer pressure and conformity or role expectations. Further, fear could still be a motivation, though courage had not permitted a willing participation. So one became an unwilling but persuaded participant.

If approached for recruitment, an unwilling individual must ask himself how credible the coercion is that the recruiter is threatening; if there is no coercion or if it is not credible then the individual can again become a non-participant. If the coercion is credible, the individual will try and evade participation, rather than suffer the coercive consequences of direct refusal. Evasion of participation can be seen in »instances of simply >shirking harms [sic!] way during actions, that is, avoiding > front line< activity through footdragging or unauthorized leaving of assigned duties « (Haberer 2001: 400).

Should evasion not be possible, in some cases bribes, such as money, jewellery or even alcohol, may be acceptable to the recruiter, as it was sometimes the case in Rwanda (Straus 2006: 145; Gourevitch 1998: 127). Finally, if so far non-participation has not been an option the individual faces a decision. Either he must participate or refuse to participate and become a non-perpetrator, but this refusal entails also that he decides to accept the anticipated punishment. His perception might have been wrong and, in actual fact, no punishment follows; otherwise this punishment could be anywhere from being beaten or socially ostracised to being put to death. 
If one does not refuse, at last, one has no options left and one is a coerced participant.

While this model is framed as a rational thought process, often assessments of the situation must be made so quickly that individuals just participate for lack of perceiving any alternatives. However, when participating for weeks, months or years, successively this process can still be played through.

This model is a first attempt to formalise who participates in genocide and how this participation occurs, attempting to portray the decision-making from a rational perspective, while not neglecting that different actors can have different preference hierarchies. Thus, here three categories of perpetrators and those who do not participate (though these could be further differentiated too) are identified. This differentiation resembles Philip Zimbardo's (2008: 208) typology of his experimental prison guards: The type of perpetrator here identified as willing participants correspond to those guards who were enthusiastic and sometimes came to abuse their power; second, there were the unwilling, but ultimately persuaded participants, Zimbardo's tough but not abusive guards, who just went along with it, fulfilling their duty but no more; and finally the coerced participants who did everything to get out of participation but failed and felt they must - while being the least similar category, these are equivalent to those who resisted the opportunities of power where they could and sought to help the prisoners, but nonetheless they stayed guards and did not quit the experiment.

\section{How good is the model and how could it be tested?}

This article has tried to pull together strands from all corners of genocide studies, from social-psychological experiments, and political science, sociological as well as journalistic accounts of individual case studies, synthesising all this diversity into two relatively parsimonious models. Given the brevity of this article, it can only be a preliminary sketch. However, the aim was to incorporate the fundamental, yet extremely disparate previous findings and systematically assess whether they are necessary and sufficient determinants, or facilitative factors; this model should be able to account for participation in many different cases. One central premise is the interaction of situational and dispositional factors, with situations affecting and being affected by the individuals in them, people's behaviour and their attitudes influencing each other reciprocally. This model has succeeded in not dichotomising these different facets but has incorporated them successfully, emphasising, for instance, that situations of uncertainty can interact with peer pressure or how ideologically tainted out-group identification affects an individual's perception of 
security situations and causes fear. It seems appropriate to mention here that, while it is evident that situational pressures are pivotal in this explanation, this does not exempt individuals from their personal responsibility for the deeds they committed. As the second model demonstrated, participation is a decision and thus entails full personal responsibility. Each person faced choices, albeit difficult ones; the model is not morally exculpatory as there have always been people in each group who decided to say »No! « in spite of the situational pressures.

Unfortunately, model 2 does suffer from the fact that it is inferred to a large degree from just the case of Rwanda and must be expanded to include empirical results from other cases. Furthermore, model 2 is too static to depict real-life dynamics, particularly under ever-evolving contexts in genocidal situations - this must be expanded in future research with testable hypotheses being derived from the models, suggesting in a probabilistic nature how a factor impacts the likelihood of a person becoming a perpetrator.

Also, the model cannot predict the intensity of participation: the model can only say whether it is possible that someone will participate or not, and not whether he will become a hardcore killer. Potentially, the higher the probability of participation (the more variables are present), the higher the intensity, though this is mere speculation and must be tested.

Finally, this model is also capable of coping with temporally fluctuating and multiple motivations. Participation remains plausible as long as one of the nine necessary conditions is fulfilled; should this no longer be the case, the individual can attempt to cease his participation, however, if he is unwilling to accept coercive punishment, he may just change status from a willing or persuaded participant to a coerced participant.

\section{Conclusion}

This article has presented a synthesised model of the motivations people have to participate in genocide, identifying obedience to authority, peer pressure, role expectations, coercion, opportunism, fear, threatened egotism, ideology and sadism as individual causes which make participation possible. These were augmented or triggered by various macro-level background variables, such as insecurity, a strong state or a monolithic society. Further, they were complemented by facilitative factors which were not sufficient to cause perpetration, nor necessary; however, when present they made possible participation much more likely. In a second step, it was modelled how people become willing, unwilling but persuaded or coerced participants and what options for exit there are along the way. This emphasised the fact 
that participation is never inevitable despite strong situational pressures and that a decision must always be made.

The contribution of this article to the study of genocide has been to systematically assess the contemporary literature and categorise influential factors as either determining motivations for perpetration or facilitating participation, herewith trying to bring together a disparate mess of individual theories, each holding for one case but not for many others. This paper has demonstrated that no monocausal answer can be given to the questions of participation, no one factor drives genocide. This complexity of the phenomenon has driven Christian Gerlach (2010) to embrace the concept of »extremely violent societies«, with which he purports to be able to better explain the broad reasons behind mass violence. However, this paper has demonstrated that it is also possible within the framework of genocide to delve right into the depths of this phenomenon and start to unravel the complexity at the micro level.

In pursuance of a micro-level perspective on genocide, both models should be empirically tested to see if the variables group in certain patterns and also whether the pathways into participation (and non-participation) hold true. This will necessitate further comparative interviewing of former genocide perpetrators, a process which is riddled with methodological difficulties given the sensitive nature of the topic at hand. While it is hard to differentiate between genuine and stated motivations, a struggle to build enough rapport to garner the trust of perpetrators in interview situations and - nigh impossible - to counteract memory loss, Scott Straus (2006) and Omar McDoom (2008) have demonstrated that it was possible in Rwanda. Similar approaches should be followed in interviewing perpetrators of other genocides, such as Cambodia or Bosnia.

Research on micro-level participation in genocide is an important research topic and through an increased comprehension of this topic, ultimately perhaps a deeper recognition can set in as to what the dynamics are that bring ordinary people to commit such heinous crimes. Only with this insight will it be possible in future to nourish factors that quell genocide in its inception and to empower non-participants. In such an important field for humankind, political science must strive for greater understanding and more general theories. 


\section{Literature}

André, Catherine/Platteau, Jean-Philippe 1998: Land Relations under Unbearable Stress: Rwanda Caught in the Malthusian Trap, in: Journal of Economic Behavior \& Organization 34: 1, 1-47.

Arendt, Hannah 1963: Eichmann in Jerusalem: A Report on the Banality of Evil, New York, NY.

Asch, Solomon 1963: Effects of Group Pressure Upon the Modification and Distortion of Judgments, in: Guetzkow, Harold (ed.): Groups, Leadership and Men: Research in Human Relations, New York, NY, 177-190.

Bandura, Albert 1999: Moral Disengagement in the Perpetration of Inhumanities, in: Personality and Social Psychology Review 3: 3, 193-209.

Baum, Steven 2008: The Psychology of Genocide: Perpetrators, Bystanders, and Rescuers, Cambridge.

Baumeister, Roy 2002: The Holocaust and the Four Roots of Evil, in: Newman, Leonard/Erber, Ralph (eds.): Understanding Genocide: The Social Psychology of the Holocaust, Oxford, 241-258.

Baumeister, Roy/Campbell, Keith 1999: The Intrinsic Appeal of Evil: Sadism, Sensational Thrills, and Threatened Egotism, in: Personality and Social Psychology Review 3: 3, 210-221.

Browder, George 2003: Review Essay: Perpetrator Character and Motivation: An Emerging Consensus?, in: Holocaust and Genocide Studies 17: 9, 480-497.

Browning, Christopher [1994] 2001: Ordinary Men: Reserve Police Battalion 101 and the Final Solution in Poland, New York, NY.

Chalk, Frank/Jonassohn, Kurt 1990: The History and Sociology of Genocide: Analyses and Case Studies, New Haven.

Fein, Helen 1990: Genocide: A Sociological Perspective, in: Current Sociology 38 : 1, 32-91.

Fletcher, Luke 2007: Turning interahamwe: Individual and Community Choices in the Rwandan Genocide, in: Journal of Genocide Research 9: 1, 25-48.

Fujii, Ann Lee 2009: Killing Neighbours: Networks of Violence in Rwanda, Ithaca, NY.

Gerlach, Christian 2010: Extremely Violent Societies: Mass Violence in the Twentieth Century World, Cambridge.

Goldhagen, Daniel 1996: Hitler's Willing Executioners: Ordinary Germans and the Holocaust, London.

Gourevitch, Philip 1998: We Wish to Inform You That Tomorrow We Will Be Killed with Our Families, London. 
Haberer, Eric. E. 2001: The German Police in Belorussia, 1941-1944, Part III: Methods of Genocide and the Motives of German Police Compliance, in: Journal of Genocide Research 3: 3, 391-403.

Hatzfeld, Jean 2004: Zeit der Macheten. Gespräche mit den Tätern des Völkermordes in Ruanda, Gießen.

Jones, Adam 2006: Genocide: A Comprehensive Introduction, London.

Kressel, Neil 2002: Mass Hate: The Global Rise of Genocide and Terror, Cambridge, MA.

Kuper, Leo 1981: Genocide: Its Political Use in the Twentieth Century, New Haven, CT.

Lieberman, Evan S. 2005: Nested Analysis as a Mixed-Method Strategy for Comparative Research, in: American Political Science Review 99: 3, 435-452.

Mann, Michael 2005: The Dark Side of Democracy: Explaining Ethnic Cleansing, Cambridge.

McDoom, Omar 2008: The Micro-Politics of Mass Violence: Authority, Security, and Opportunity in Rwanda's Genocide (PhD), London.

McDoom, Omar 2012: The Psychology of Threat in Intergroup Conflict: Emotions, Rationality, and Opportunity in the Rwandan Genocide, in: International Security 37: 2, 119-155.

McDoom, Omar 2013: Who Killed in Rwanda's Genocide? Micro-Space, Social Influence and Individual Participation in Intergroup Violence, in: Journal of Peace Research 50: 4, 1-15.

Melson, Robert 1992: Revolution and Genocide: On the Origins of the Armenian Genocide and the Holocaust, Chicago, IL.

Milgram, Stanley 1963: Behavioral Study of Obedience, in: Journal of Abnormal and Social Psychology 67: 4, 371-378.

Mueller, John 2000: The Banality of Ethnic War, in: International Security 25: 2, 42-70.

Newman, Leonard 2002: What Is a »Social-Psychological« Account of Perpetrator Behaviour? The Person Versus the Situation in Goldhagen's Hitler's Willing Executioners, in: Newman, Leonard/Erber, Ralph (eds.): Understanding Genocide: The Social Psychology of the Holocaust, Oxford, 43-67.

Petersen, Roger 2002: Understanding Ethnic Violence: Fear, Hatred, and Resentment in Twentieth-Century Eastern Europe, Cambridge.

Posen, Barry 1993: The Security Dilemma and Ethnic Conflict, in: Survival 35: 1, 27-47.

Ragin, Charles 1987: The Comparative Method, Berkeley, CA. 
Roth, Paul 2004: Hearts of Darkness: »Perpetrator History« and Why There Is No Why, in: History of the Human Sciences 17: 2-3, 211-251.

Rummel, Rudolph 1994: Death by Government, New Brunswick, NJ.

Semelin, Jacques 2005: Purify and Destroy: The Political Uses of Massacre and Genocide, New York, NY.

Snyder, Jack/Jervis, Robert 1999: Civil War and the Security Dilemma, in: Snyder, Jack/Walter, Barbara (eds.): Civil Wars, Insecurity and Intervention, New York, NY, 15-37.

Staub, Ervin 1989: The Roots of Evil: The Origins of Genocide and Other Group Violence, Cambridge.

Staub, Ervin 2002: The Psychology of Bystanders, Perpetrators, and Heroic Helpers, in: Newman, Leonard/Erber, Ralph (eds.): Understanding Genocide: The Social Psychology of the Holocaust, Oxford, 11-42.

Steiner, John 1980: The SS Yesterday and Today: A Sociopsychological View, in: Dimdale, Joel (ed.): Survivors, Victims, and Perpetrators: Essays on the Nazi Holocaust, New York, NY, 405-456.

Straus, Scott 2006: The Order of Genocide: Race, Power, and War in Rwanda, Ithaca, NY.

Valentino, Benjamin 2004: Final Solutions: Mass Killing and Genocide in the Twentieth Century, Ithaca, NY.

Waller, James 2002: Becoming Evil: How Ordinary People Commit Genocide and Mass Killing, Oxford.

Zimbardo, Philip 2008: The Lucifer Effect: Understanding How Good People Turn Evil, New York, NY.

\section{Der Autor}

Timothy A. Williams ist Promotionsstudent an der Freien Universität Berlin, wissenschaftlicher Mitarbeiter am Zentrum für Konfliktforschung der Philipps-Universität Marburg sowie Geschäftsführender Direktor von Beyond Violence.

E-Mail: timothy.williams@staff.uni-marburg.de 